811.163.41’373.2:929 Маројевић P. https://doi.org/10.18485/sj.2018.23.1.5

МИХАИЛО М. ШЋЕПАНОВИЪ

Универзитет у Београду

Филолошки факултет

ДРАГА И. БОЈОВИТ ${ }^{* *}$

Универзитет Црне Горе

Филолошки факултет у Никшићу
Оригинални научни рад

Примљен: 04. 01. 2018.

Прихваћен: 29. 01. 2018.

\title{
ОНОМАСТИЧКЕ ТЕМЕ (И РЕШЕЊА) ПРОФЕСОРА РАДМИЛА МАРОЈЕВИЋА
}

\begin{abstract}
Аутори у наведеном прилогу разматрају научни допринос професора Радмила Маројевића као једног од главнијих утемељивача српске ономастичке мисли и као научника који је својим научним решењима осветљавао тамна места на српској ономастичкој мапи. Уз осврт на професорова решења методолошког приступа ономастичким темама, као незаобилазна за савремена и будућа ономастичка истраживања у србистици, указујемо и на кључна тематска решења у ономастичким категоријама (антропонимија и топонимија) која су, на основу Маројевићевих радова, утрла пут будућим истраживачима из датих области ономастичке проблематике.

Кључне речи: ономастика, антропонимија, топонимија, методолошки приступ, посесивни суфикси, трагови дуала, Радмило Маројевић.
\end{abstract}

0. Развојни пут савремене српске ономастичке мисли не може се ни сагледати ни осветлити без увида у научни допринос професора Радмила Маројевића као једног од њених утемељивача, главног наследника бошковићевских

*mihail.scepanovic@gmail.com

**dragabojovic@t-com.me 
решења, и неприкосновеног аналитичира морфонолошких шавова, затамњених вековним срастањима под опном српских и општесловенских топонима. Због тога се и развојни лук српске ономастике може међити од Р. Бошковића, преко П. Ивића, М. Пешикана до А. Ломе и Р. Маројевића. То су главни заслужници, уз низ корисника и приложника, који су резултате српске ономастичке науке уврстили у научно поуздан општесловенски ономастички корпус.

0.1. Двема монографијама Посесивне категорије у руском језику и Посесивне изведенице у староруском језику (В. библиографију у Прилогу уз овај рад), а нарочито научним решењима која тамо износи, Маројевић отвара пут у тумачењу српских топонима, нарочито оним антропонимског порекла (нпр. Морача, Мораково и сл.), који су све до њега површно а и погрешно тумачени. И мало је радова у Маројевићевој библиографији, чак и синтетичког типа, а да у њима аутор није померио научно решење до извесности. То нам је и задатак који смо себи поставили у овом раду. Истина, пошто је ово годиште Српског језика посвећено професоровом јубилеју, Редакција нам је омеђила обим, тако да је овај текст скраћена верзија знатно обимнијег рада који ће се појавити на другом месту.

0.2. Онолико колико смо обавештени, код Маројевића нема климавих решења или су његова решења толико сигурна да их је било тешко кориговати. Да би се ваљано сагледао ономастички опус професора Маројевића, тесна би била и једна монографија. Мада, ако се погледа тематизовано Маројевићев ономастичкли опус, може се анлизирати у три правца, као његов троструки допринос српској ономастици. Прво, и најважније, Маројевић је утемељио методологију ономастичких истраживања јер је до њега истраживање овог типа било затамњено, и више дато у етимолошким обрисима. То значи да је Маројевић поставио редослед у сагледавању ономастичке анализе, од историје питања, поузданости документованих чињеница до филигрантски изведених анализа на бошковићевски начин. То је његовим радовима дало узорну концизност без икаквих редудантских натруњености.

0.3. Неприкосновен у научним поступцима, професор Радмило Маројевић је веровао и верује једино у ауторитет научне истине. И без претеривања, сагледавајући његову биобиблиографију, да̂ се уочити да је његова вера у ауторитет научне истине засметала у српској учмалој научној средини неким, својевремено, владајућим ауторитетима, па им је делимично успевало да Маројевића склоне, а да се његов научни допринос у палеославистици и србистици почне занемаривати. Бриткост полемичког израза професора Маројевића је њему самоме постала препрека коју осликава чињеница да данас немамо његова сабрана или изабрана дела, како би се српска лингвистичка јавност у потпуности информисала о научним доприносима овог, после Р. Кошутића и Р. Бошковића, изузетног, на србистичкој и палеославистичкој тематској равни - особеног истраживача. 
1. Антропонимске теме (и решења) (Прилог: т. 1, 2, 3, 5, 7, 9, 10, 11, 13, 14, 15, 16, 19, 20, 22, 27, 29, 30, $32,33,34,48,49,50,51,59,60,62,63,68,69,71,75,79,81,84,85$, $86,88,91$ и 92)

Да је утемељивач методологије ономастичких истраживања, професор Маројевић је то индиректно показао на Петој ономастичкој конференцији (библиографија у прилогу), где он децидирано износи: „Мој реферат је, прво, имао методолошку усмереност (курзив наш), да покаже проблеме у испитивању фолклорне ономастике, а није имао за циљ да са свих страна осветли илустративне примере. И друго, желео сам да покажем могућност примене метода творбено-семантичке реконструкције у овој области". Колико је неопходна методолошка прецизност у расветљавању одређене ономастичке тематике показује Маројевићев рад Фолклорна ономастика у дијахронији и проблеми њеног лингвистичког испитивањ а у коме аутор, већ у уводним напоменама, разматра методолошка питања у истраживању. Наиме, он у приступу преиспитивању фолклорне ономастике у дијахронији узима као обавезне три интерпретације ономастичких података. Прва интерпретација се односи на ономастичку реалност епохе која би се могла узети као примарна интерпретација ономастичких података. Друга интерпретација или, како аутор каже, други синхрони пресек који није временски одређен, а односи се на песничку интерпретацију којом се може првобитни ономастички лик преиначити или друкчије осмислити са његовим уметничким значењем у фолклорном систему. И на крају, трећа интерпретација или синхрони пресек одражава језичко осећање епохе којој припада последњи народни певач или приповедач који приноси податке записивачу. Аутор закључује да су „тешкоће у лингвистичком испитивању ономастике фолклора резултат специфичног укрштања наведених синхроних пресека и трију интерпретација ономастичких података”.

1.1. Аутор у раду који овде презентујемо као илустративни, мада се скоро сви његови радови на овај начин могу сагледавати, анализира примере из друге књиге Српских народних пјесама Вука Ст. Караџића „у којој су пјесме јуначке најстарије”, а то су следећи антропоними: а. Југ Богдан: указујући да је у овом сложеном антропониму прва компонента скраћено словенско име, а друга компонента калк грчког имена; б. Девет Југовића: указујући да је облик Југовић у синтагми девет Југовића, према савременом језичком осећању презиме, и то би била секундарна интерпретација ономастичких података у односу на примарну интерпретацију по којој је облик Југовић патроним (име по очевом имену). Затим следе прецизне анализе антропонима: Југовића мајка, Бановић Страхиња - Страхињић Бан, Обилић Милош - Кобилић Милош, Петрова Црква - Петрова... (в. Прилог, т. 19, 81-86)

Ако сагледамо уводне напомене уз овај одељак, јасно се указује однос између аналитичког приступа антропонимском примеру уз поштовање прецизне и адекватне методолошке поставке. 
1.2. Годину дана раније од претходно разматраног рада, професор Маројевић у раду Словенски антропоними методолошки утемељује приступ обради питања из словенске антропонимије. Али, да би то постигао аутор је морао да разреши терминолошки проблем тј. да дефинише појам антропонимска категорија. Ту Р. Маројевић наводи: „Под појмом антропонимска категорија подразумевамо тип именовања лица који се одликује и формално-граматички - има посебну творбену структуру, и семантички - има посебно ономатолошко значење. У овом смислу антропонимске категорије су компоненте које чине антропонимски систем једног језика и културе”. На основу оваквог приступа, аутор је у овој краткој студији могао и донети јасан и неприкосновено прецизан закључак: „Савремени словенски антропонимски системи битно се разликују и међусобно и у односу на прасловенски антропонимски ситем. Док смо у прасловенском имали двочлане мушке антропониме (лично име и име по оцу) и двочлане женске антропониме (лично име и име по мужу), источнословенски језици имају трочане и мушке и женске антропониме (лично име, име по оцу и презиме), јужнословенски и западнословенски језици имају двочлане и мушке и женске антропониме (лично име и презиме)" (Прилог, т.15, 195).

Маројевићевски речено, сагледавање антропонимских категорија општесловенског језика мора се посматрати кроз три типа именовања лица са посебном формалном и посебном семантичком структуром. То узрокује и добијање прецизних закључака о слици антропонимског стања у словенским језицима. С друге стране, отвара могућности за сагледавања и објашњења свих оних замагљених питања које диктирају проблеми из словенске антропонимије.

2. Топонимске теме (и решења)

(Прилог: т. 4, 6, 11, 13, 16, 17, 18, 21, 24, 25, 26, 28, 29, 31, 33, 34, 36, 37, $38,39,40,41,42,45,46,48,50-59,61,64,65,68,71,80,86,89-93)$

У својим монографијама о посесивима (Прилог, т. 11, 17, 91, 92), професор Маројевић је решио главне правце развоја посесивних суфикса у словенским језицима. То му је омогућило да решења до којих је дошао у сопственим истраживањима, а ослоњен на радове Радослава Бошковића и богату руску литературу - у каснијим својим истраживањима, на основу примера из српске антропонимије и топонимије, осветли читаву лепезу проблема, пре свега примењујући историјску творбу речи и историјску семантику. Тако на пример у раду О етимологији топонима Косово и етника Косовац $и$ Косовар аутор показује на који је начин настао топоним Косово преко двочланог имена Косово поље супстантивизацијом адјектива од кога су могли једино настати, по природи творбе српскога језика, етници Косоваи и Косовка, док је етник Косовар настао посредством творбеног обрасца преузетог из албанског језика. У раду је видљиво на који начин и са коликом аналитичком прецизношћу аутор 
образлаже своје тврдње пратећи развој овог топонима од прасловенског језика до његовог савременог фонетског лика. „С обзиром на акценатску подударност - наводи професор Маројевић - посесивног облика са обликом множине и на значење множинске припадности, ми бисмо временски лоцирали постанак топонима са временом када је перинтеграцијом настао сам посесивни суфикс -ovъ. То значи да је топоним Косово настао додавањем некадашњег посесивног суфикса -ъ <-os које је додавано основинском - са оним акценатским ликом основе коју си имали генитив и датив једнине. И, наравно, била је различита судбина изведеница једног и другог типа. Изведенице са једнинском творбеном базом прошириле су се на основе старе о̆-деклинације, као продуктивни тип, док се изведенице са множинском творбеном базом задржале на овом првобитном морфолошком оквиру, са слабом посведоченошћу у словенској топомнимији” (Прилог, т. 46, стр. 63-64, и т. 52).

Ослањајући се на резултате које дају И. Воронина и А. Грошева (1987, 202-232), Маројевић закључује: „У албанском је творба имена становника места помоћу суфикса - $a r$ сасвим обична, а сам суфикс је у овом језику непосредно преузет из латинског -ârius, као и у неким другим балканским језицима, проширивши на новом терену оквире своје употребе”. Другим речима, облик Косовар је преузет из говора косовских Албанаца и аутор доказује да није у складу са творбеном семантиком српског језика. Из данашње перспективе, то показује и његова савремена употреба у пејоративном значењу, нарочито за исељенике с подручја Косова и Метохије који се као придошлице нису добро сналазили код староседелачког живља. Без обзира на чињеницу да је албански лик етника Косовар и пејоративан, и непримерен творбеној структури српског језика, данас је у личним документима становника Косова и Метохије, у рубрици држављанство, уписан назив Косовар (потврђује Рамуш Харадинај у интервјуу Миломиру Марићу у емисији Ћирилииа, Нарру-телевизија, 16. 04. $2018,21 \mathrm{~h}-$, ). То је и најбољи показатељ како се још један балканизам угнездио у творбено-семантичку структуру српског језика, пре свега под политичком присилом.

Илустративан пример за наш увид у истраживачке захвате професора Маројевића представља рад Из ономастичке историје 1-2, (Прилог, т. 48, стр. 67-69 и т. 50, 65), нарочито његов други део Од Цетиње воде до Ријеке Црнојевића, у коме, после убедљиве анализе, доказује да је „хидроним и ојконим Ријека Црнојевића настао релативно касно, пред крај боравка Црнојевића на историјској сцени". То аутор закључује више на основу песме Женидба Максима Црнојевића у којој се та река још звала Цетињ $а$ вода, а мање на основу познате посведочености новог имена у писаним изворима. Маројевић подвлачи да „не треба сметнути с ума ни то да је у неком периоду паралелно употребљавано старо име, па је доспело и у памћење народног певача, и ново име воденог објекта, као ни то да два имена ни тада нису били 
синоними - разликовали су се у погледу дужине воденог тока који се њима означавао". Занимљиво је да закључну реченицу аутор оставља у завршној фусноти накнадно потврђујући новим примером: „из свега изнетог произилази да је Цетиња вода спадала у реке понорнице и тако се уклапала у продуктиван географски тип у крашком терену, у оба своја тока река је првобитно названа истим именом (потпуни паралелизам у том погледу представља понорница Зета)". Занимљиво је да је песму Женидба Максима Црнојевића из друге перспективе посматрао и академик Александар Лома $(2002,120,303)$ у наслову Одрази трофункиионалне идеологије у песмама о пропасти српских земаља у књизи Пракосово, цитирајући стих „од Жабљака до воде Цетиње” да би хидроним Цетиња оставио у регистру географских, етничних, историјских и традиционалних имена наводећи: „Цетиња, пресушна речица у Цетињском пољу” што унеколико потврђује раније Маројевићеве наводе.

Маројевићева решења су јасна и у свој својој концизности прецизна. Аутор наводи неопходну литературу и изворе за своја разматрања, мада некад изгледа да има и превише самоцитата, али када се узме у обзир сама тематика његових ономастичких тема и остварених решења онда се самоцитатност, што је у данашњој научној верификацији пожељно - и подразумева. Друкчије речено, онај ко је способан да урони у творбено-семантичке и историјске реконструкције често веома замагљених топонимских ономастичких ликова, мора имати ослонца и на континуитет свог научног поступка. Тако да се мозаичност његових текстова са свим својим неприкосновеним приносима лингвистичкој науци може, кад би простор дозволио, сложити у једну и коначно остварену тему српске ономастике. Чак и тамо где и не искористи све понуђене изворе, професор Маројевић ће у складу са неопходним научним поштењем признати зашто их није искористио и то образложити. Уз ову нашу напомену илустративна је нпр. фуснота број 13 из претходно цитираног рада (Прилог, т.48, стр. 66), где он наводи децидирано да је свој чланак написао пре него што је сазнао за истраживање Драгутина Костића, које „садржи податке којим би се још могло поткрепити наше разматрање антропонимских ликова, али те податке нисмо укључили пошто наш чланак не претендује на исцрпност грађе него на уверљивост творбено-семантичке и историјске реконструкиије" (курзив наш).

Управо овакав приступ да се сагледа творбено-семантичка реконструкција на основу историјске подлоге илуструје и Маројевићев кратак осврт $O$ постанку топонима Морача. Поштујући редослед у истраживачком поступку да прво осветли историју питања, Маројевић полази од Маретићевог тумачења (Рјечник JАЗУ, VI, 928) по коме он географско име Морача тумачи према речи море тј. велика вода по коме је за Маретића примаран хидроним (река у Црној Гори, а хороним је секундаран, земља око те воде) што аутор ишчитава из редоследа значења из Рјечника ЈАЗУ. Да је Маретић овде био 
више ослоњен на народну етимологију, Маројевић ту, као узгредно наводи друго народно етимологисање или како каже псеудолегенду о постанку села Моракова, „по којој је некад на подручју села било језеро које је било велико па га је народ звао море, отуда је и село добило име Мораково" (Прилог, т. 1, стр. 213-215). Није Маројевић овде случајно поменуо ојконим Мораково јер, у географском смислу, то је скоро исти ареал. После прецизне анализе, Маројевић закључује да топоним Морача представља „femininum посесивног придева moračb, morača, morače, изведеног помоћу суфикса -jb од личног имена - Morakb” закључујући, дакле, да је Морача означавача земљу која је била у Мораковом поседу, а касније је то име пренето на реку. Чињеницу да су хидроними старији од ојконима бар у досадашњим реконтрукцијама, Маројевић свој закључак притврђује чињеницом да Морача земља обухвата само горњи ток реке Мораче.

Што се тиче тумачења ојконима Мораково (село источно од Никшића), професор Маројевић овде види одраз посесивног суфикса -оv којим су се изводили примери именица на - $a k$ после губљења суфикса -jb. Старину самог топонима у овом случају Маројевић везује за крај XIV века јер је још тада посесивни суфикс -jb, према Бошковићевом тумачењу (1978:446), у штокавском дијалекту био још жива категорија”. Да би притврдио хипотезу о постајању личног имена Морак које је само сачувано у два анализирана ојконима, Маројевић посеже за чињеницом да су лична имена са суфиксом -ак била некад веома продуктивна, наводећи примере из Рјечника ЈАЗУ као Берак, Дујак, Војак, Медак, Милак, Петак, Радак, Селак, дајући потврде да су и наведена имена засведочена у српској топонимији. Проведеном анализом аутор долази до стабилног закључка: „Топоними Морача и Мораково имају исто порекло: оба су посесивни придеви од личног имена Морак, први изведен помоћу старог посесивног суфикса -jb, други - помоћу суфикса -ов који га је заменио. Морача је настала (топоним Морача) кад је суфикс -јь био жив и продуктиван, а Мораково (топоним) - кад је суфикс -јь био мртав".

У једном од својих најкраћих радова, скоро по угледу на Радосава Бошковића (на страници и по са резимеом), Маројевић разрешава питање трагова дуала у словенској топонимији. На основу топонима Кýma, село у Жупи Никшићкој, даје његов савремени граматички опис plulare tantum neutrum поткрепљујући то парадигмом према падешким ликовима Kýma (номинатив, акузатив, вокатив), Kýmā (генитив), Kýmuмa (датив, инструментал, локатив). Иако уз опрез, аутор претпоставља да је топоним Кута словенског порекла. Своју претпоставку ослања на три чињенице: „1. Да је несловенског порекла, топоним би у словенски деклинациони ситем ушао као singulare tantum; 2. У топониму се препознаје словенски корен кym- < kqnt-, који је продуктиван у топонимији; 3. У непосредној близини су топоними словенског порекла. Тако на пример суседно место Миоље Поље < *Mihol'e pol'e (облик *Mihol'e је 
neutrum посесивног придева изведеног помоћу старог словенског суфикса -jb од личног имена Михол, варијанте имена Михаил" према потврдана из Рјечника JAЗУ VI, 650 (Прилог, т. 4, стр. 153). Аутор наставља да своју претпоставку докаже објашњавајући деклинациону специфичност топонима Кута и његову везу са кym- < kqnt-, ослањајући се на Скоково тумачење $(\mathrm{ERj}, 2,248)$ по коме именица кут има два основна значења „1. ugao, nugao; 2 . toпоним у sing и pl”. Даље следе потврде са сингуларним и плуларним облицим кут, односно кути, на основу чега аутор изводи закључак: „топоним Кута, по нашем мишљењу, чува некадашњи облик номинатива дуала именице кym- < kont- те је његово значење било два кута 'два угла'”. Маројевић овде не занемарује ни ванлингвистичке чињенице указујући на географски положај села и конфигурацију терена: „Кута су окружена са свих страна планинским падинама, осим дела јужне стране, а у селу се јасно издвајају две увале, два угла". На овај начин аутор указује на методолошку доследност, да је некад сем творбено-семантичке реконструкције, пожељна и географска дескрипција ареала како би резулатати анализе били што уверљивији. У овом случају, уверљивост анализе је несумњива.

3. И да закључимо. Ономастичке теме и решења професора Радмила Маројевића сагледавали смо у три правца. Прво, на методолошкој равни где професор даје аналитички развој српске ономастичке мисли од прасловенског до садашњег стања у синхроној равни, указујући на путеве творбено-семантичке реконструкције са ослонцем на историјску подлогу. Како би решења била адекватније утемељена, професор Маројевић смислено прецизира адекватну ономастичку терминологију уводећи термин антропонимске категорије у антропономастичким темама. То је омогућило његовим настављачима, истраживачима на овом научном пољу, да преусмере своја истраживања или другим речима да их прецизније научно презентују.

Дајући класификацију посесивних словенских суфикса у историјском развоју, Маројевић утемељује јаснију реконструкцију читавих ономастичких класа и не само топонима који су били све до њега, у већини случајева, „тамнога постања". На тај начин он је српској ономастици презентовао моделе који су проистекли из његових ономастичких решења. То је, дакле, на неки начин истраживачко упутство за пут у творбено-семантичку реконструкцију, за анализу одабраних, ономастичких јединица, што је немерљив допринос српској ономастици. 


\section{ПРИЛОГ}

\section{Библиографија ономастичких радова професора Радмила Маројевића (Избор)}

1. Зборник [Матице српске] за филологију и лингвистику, Нови Сад, 1979, [књ.] $\mathrm{XXII} / 2$ :

1. О староруским именима Рацлаль $и$ Горислалиць / Радмило Маројевић. - Стр. 85-88. [Резиме на руском језику].

2. О постанку топонима Морача / Радмило Маројевић. - Стр. 213-215.

2. О постанку топонима Морача / Радмило Маројевић. Нови Сад: [Матица српска], 1979, стр. 213-215. (П. о.: Зборник [Матице српске] за филологију и лингвистику; 22, 2, 1979).

3. Оппозиция определенных и неопределенных форм притяэсательных прилагательных. (К вопросу о природе имен типа $\mathrm{V}$ ьsevoložaja в древнерусском языке) / Р. [Радмило] Мароевич. - Вопросы языкознания, Москва, 1981, № 5, стр. 106-118.

4. Постанак топонима Кута. (Уз питање о траговима дуала у словенској топонимији) / Радмило Маројевић. - Ономатолошки прилози, Београд, 1981, књ. II, стр. 153-154. [Резиме на руском језику].

5. Јужнословенски филолог, Београд, 1982, књ. XXXVIII:

1. Прасловенска adiectiva possesiva типа Tvorimiríič (од патронима типа Tvorimiríčь), ғиххова судбина и трагови у словенским језищима / Радмило Маројевић. - Стр. 89-109. [Резиме на руском језику].

6. Постанак топонима Рудежа $u$ Рубежа. (Јом два прилога питању о траговима дуала у словенској топонимији) / Радмило Маројевић. - Ономатолошки прилози, Београд, 1982, књ. III, стр. 151-154. [Резиме на руском језику].

7. „Пирогощая” у „Слову о полку Игореве” и староруским летописима / Радмило Маројевић. - Зборник [Матице српске] за славистику, Нови Сад, 1982, књ. 23, стр. 211-214.

8. Зборник [Матице српске] за филологију и лингвистику, Нови Сад, 1982, [књ.] $\mathrm{XXV} / 2$ :

2. Ономатолошки прилози, II, Београд, Српска академија наука и уметности, 1981. [Приказ] / Радмило Маројевић. - Стр. 146-155.

9. Прасловенска имена по мужу, њихови трагови и судбина у српскохрватском језику / Радмило Маројевић. - Књижевност и језик, Београд, 1982, XXIX, бр. 3-4, стр. 231-234; 1983, XXX, бр. 1-2, стр. 134. [Резиме на руском језику].

10. Имена по мужу у српскохрватском језику (компаративно-историјски аспекат) / Радмило Маројевић. - Х конгрес на Сојузот (Струга, 6-10. Х 1982): Резимеа на рефератите. Скопје: Сојуз на славистичките друштва на Југославија, 1982, стр. $55-56$.

11. Посесивне категорије у руском језику: (у своме историјском развитку и данас)/ Радмило Маројевић. Београд: Филолошки факултет, 1983, 206 стр. (Монографије, књ. LV). 
12. Заметки по историческому словообразованию. 1-2 [Авторизованный перевод И. П. Петлевой] / Р. [Радмило] Мароевич. - Этимология: 1981, Москва: Наука, 1983, стр. 44-49:

1. Форма ғанна в древнерусских летописях. - Стр. 44-46.

2. Старославянские притяжательные прилагательные типа Salańь. - Стр. 46-49.

13. Праславянские adiectiva possessiva mипа Tvorimiŕičь (от патронимов типа Tvorimíričь), их судьба и следы в славянских языках / Р. [Радмило] Мароевич. - Резюме докладов и письменных сообщений. IX международный съезд славистов. Киев, сентябрь 1983. Москва: Наука, 1983, стр. 104-105.

14. Антропонимске категорије у староруском језику. (Прилог питағу реконструкиије прасловенског антропонимског система) / Радмило Маројевић. - Ономатолошки прилози, Београд, 1983, књ. IV, стр. 137-177. [Резиме на руском језику].

15. Словенски антропоними / Радмило Маројевић. - Ономатолошки прилози, Београд, 1984, књ. V, стр. 183-195. [Резиме на руском језику].

16. Црногорски говори. Резултати досадашњих испитивања и даљи рад на њиховом проучавању. Радови са научног скупа (12. и 13. мај 1983). Титоград: Црногорска академија наука и умјетности, 1984:

2. Методолошка питања ономастичких истраживања / Радмило Маројевић. - Стр. 237-242. [Резиме на руском језику].

2. [О топонимима Никшић $u$ Никшићи] / Радмило Маројевић. - Стр. 251-252.

17. Посесивне изведенице у староруском језику: Антропонимски систем. Топонимија. „Слово о полку Игореве” / Радмило Маројевић. Београд: Филолошки факултет, 1985, 158 стр. (Монографије, књ. LIX).

18. Прилози творбено-семантичкој реконструкиији староруских топонима / Радмило Маројевић. - Ономатолошки прилози, Београд, 1985, књ. VI, стр. 21-58. [Резиме на руском језику].

19. Zbornik referata i materijala $\mathrm{V}$ jugoslovenske onomastičke konferencije [12-15. X 1983]. Sarajevo, 1985:

1. [O tvorbenoj strukturi praslovenskih patronima. Napomene uz referate A. Superanske i A. Peca] / Радмило Маројевић. - стр. 41-42.

2. Фолклорна ономастика у дијахронији и проблеми њеног лингвистичког испитиваға / Радмило Маројевић. - Стр. 81-86. [Резиме на руском језику].

3. [Završna reč u diskusiji o referatu o problemima lingvističkog ispitivanja folklorne onomastike u dijahroniji] / Радмило Маројевић. - стр. 107.

4. [O formiranju srpskih prezimena. Napomene uz referate M. Grković i J. Vončine] / Радмило Маројевић. - Стр. 245-246.

5. [O antroponimu Molibogъ] / Радмило Маројевић. - Стр. 298-299.

20. Имена по мужуу у староукрајинском језику/ Радмило Маројевић. - Ономатолошки прилози, Београд, 1986, књ. VII, стр. 125-139. [Резиме на руском језику].

21. О једном тумачењу староруских назива градова. [Приказ књиге: В. П. Нерознак. Названия древнерусских городов. Москва, 1983] / Радмило Маројевић. - Onomastica jugoslavica, knj. 12, Zagreb, 1986, стр. 227-239. 
22. IX Международный съезд славистов, Киев, сентябрь 1983 г. Материалы дискуссии. Языкознание. Киев, 1986:

1. [О испитиваюу словенске антропонимије са типолошког аспекта] / Радмило Маројевић. - Стр. 114.

23. Јужнословенски филолог, Београд, 1987, књ. XLIII:

1. О реконструкиији прасловенског система посесивних категорија и посесивних изведеница / Радмило Маројевић. - Стр. 17-40. [Резиме на руском језику].

24. О етимолошкој обради староруских топонима. (Поводом књиге: Етимологічний словник літописних географічних назв Південної Руси) / Радмило Маројевић. - Ономатолошки прилози, Београд, 1987, књ. VIII, стр. 1-24. [Резиме на руском језику].

25. Зборник Матице српске за филологију и лингвистику, Нови Сад, 1987, [књ.] $\mathrm{XXX} / 1$ :

1. О постанку топонима црква Димитрија / Радмило Маројевић. - Стр. 129-132. [Резиме на руском језику].

2. І І. М. Желєзняк, А. П. Корепанова, Л. Т. Масенко, О. С. Стрижак: Етимологічний словник літописних географічних назв Південної Руси. Київ, Наукова думка, 1985. [Приказ] / Радмило Маројевић. - Стр. 209-213.

26. Етимологічний словник літописних географічних назв Піивденої Русии / Радмило Маројевић. Нови Сад: [Матица српска], 1987, стр. 192-221 (П. о.: Зборник Матице српске за филологију и лингвистику; 30, 1, 1987).

27. О писағу руских имена. - Летопис Матице српске, Нови Сад, 1987, 163, књ. 439, св. 6, стр. 989-994.

28. Зборник Шесте југословенске ономастичке конференције (Доњи Милановац, 9-12. октобар 1985), Београд, 1987:

1. [О рефератима О. Трубачова и Н. Родића] / Радмило Маројевић. - Стр. 81-82.

2. Методолошка питања творбено-семантичке реконструкијје средњовековних топонима: (на примеру староруских назива градова) / Радмило Маројевић. - Стр. 135-139. [Резиме на руском језику].

3. [О рефератима М. Могуша, Р. Цета и В. Михајловића] / Радмило Маројевић. - Стр. 197-198.

4. [Заврина реч у дискусији о реферату о методолочким питағима творбено-семантичке реконструкиије средњовековних топонима] / Радмило Маројевић. - Стр. 209-210.

5. [O реферату Д. Вујичића] / Радмило Маројевић. - Стр. 343-344.

6. [О рефератима Б. Дабића и П. Шимуновића] / Радмило Маројевић. - Стр. 463-464.

7. [О рефератима Г. Јовановић и М. Радовић-Тешић] / Радмило Маројевић. - Стр. 631-632.

29. Ономастички ликови у фолклорном тексту (на материјалу Вукових збирки и Српског рјечника) / Радмило Маројевић. - Међународни научни скуп „Вук Караџић и његово дело у своме времену и данас": резимеа. Београд, 1987, стр. 49. 
30. Чернобиљ, а не Чернобил / Радмило Маројевић. - НИН, Београд, 22. фебруар 1987, бр. 1886, стр. 8.

31. В. П. Нерознак. Названия древнерусских городов. М., 1983, Авторизованный перевод И.П. Петлевой. [Приказ] / Радмило Мароевич. - Этимология: 1985. Москва: Наука, 1988, стр. 183-186.

32. Славистички зборник. Београд: Савез славистичких друштава СР Србије, 1988, књ. III: Транскрипција и превођење са словенских језика:

2. Руски антропоними и топоними у српскохрватском тексту: (проблеми транскрипијје и творбенограматичке адаптације) / Радмило Маројевић. - Стр. 25-34. [Резиме на руском језику].

33. Књижевни језик, Сарајево, 1988, XVII, бр. 2:

1. O transkripciji ruskih antroponima i toponima u srpskohrvatskom jeziku / Radmilo Marojević. - Стр. 105-110. [Резиме на руском језику].

2. Černobilj, a ne Černobil / Radmilo Marojević. - Стр. 117.

34. Ponovo o Černobilju / Radmilo Marojević. - Jezik, Zagreb, 1988, XXXV, br. 4, стр. 117-119.

35. Ономастички ликови у Историји о Црној Гори Василија Петровића / Радмило Маројевић. - Гласник Одјељења умјетности / Црногорска академија наука и умјетности, Титоград, 1988, књ. 8, стр. 59-78. [Резиме на руском језику].

36. Именослов ирногорских мјеста. [I]. Оногошт / Радмило Маројевић.- Никшићке новине, 17. јун 1988, стр. 8.

37. Именослов ирногорских мјеста. [II]. Никшићи, Никшић / Радмило Маројевић. - Никшићке новине, 24. јун 1988, стр. 8.

38. Именослов ирногорских мјеста. [III]. Петюица, Пошћење, Мораково / Радмило Маројевић. - Никшићке новине, 1. јул 1988, стр. 8.

39. Именослов ирногорских мјеста. [IV]. Кута, Рубежа / Радмило Маројевић. - Никшићке новине, 8. јул 1988, стр. 12.

40. Именослов ирногорских мјеста. [V]. Миоље Поље, Велимље, Будимља / Радмило Маројевић. - Никшићке новине, 22. јул 1988, стр. 8.

41. Именослов ирногорских мјеста. [VI]. Подгорица, Заград, Подград / Радмило Маројевић. - Никшићке новине, 29. јул 1988, стр. 8.

42. Именослов црногорских мјеста. [VII]. Баошиће, Озринићи, Југовићи, Ливеровићи / Радмило Маројевић. - Никшићке новине, 9. септембар 1988, стр. 8.

43. Јединство, Приштина, 1-2. октобар 1988. (Недељни додатак I, 1): 〜1. Косово - Косовац - Косовар / Радмило Маројевић. - Стр. 10.

44. К Кеконструкиии праславянской системы посессивных категорий и посессивных производных / Р. [Радмило] Мароевич. Авторизованный перевод Л. В. Куркиной и И. П. Петлевой. - Этимология. 1986-1987. Москва: Наука, 1989, стр. 121-139.

45. Дискусийна експериментальна лексикографична праия: Етимологічний словник літописних географічних назв Південної Руси / Желєзняк І. М., Корепанова А. П., Масенко Л. Т., Стрижак О. С. К.: Наук. думка, 1985. [Приказ] / Р. [Радмило] Мароевич. - Мовознавство, Київ, 1989, № 4, стр. 75-77. 
46. О етимологији топонима Косово и етника Косовац $и$ Косовар / Радмило Маројевић. - Ономатолошки прилози, Београд, 1989, књ. Х, стр. 63-65. [Резиме на руском језику].

47. К вопросу о словообразовательной структуре древнерусских мужских патронимов / Р. [Радмило] Мароевич. - Академик Василий Михайлович Истрин. Тезисы докладов областных научных чтений, посвященных 125-летию со дня рождения ученого-филолога. 11-12 апреля 1990 г. Одесса, 1990, стр. 32-34.

48. Из ономастичке историје. [1-2] / Радмило Маројевић. - Ономатолошки прилози, Београд, 1990, књ. ХІ, стр. 63-70. [Резиме на руском језику].

1. Милош Копиљић (Кобиљић, Обиљевић, Обилић) - фолклорне мене у имену косовског јунака / Радмило Маројевић. - Стр. 63-66.

2. Од Цетиње воде до Ријеке Црнојевића / Радмило Маројевић. - Стр. 67-70.

49. Двије скиие из историјске ономастике. [1-2] / Радмило Маројевић. - Косовски бој у историји, традицији и стваралаштву Црне Горе. Реферати са научног скупа. Титоград, 25. октобра 1989. године. Титоград, 1990, стр. 255-262. [Резиме на руском језику].

1. Од Косова поља до косовског симбола / Радмило Маројевић. - Стр. 255-257.

2. Милош Копиљић (Кобиљић, Обиљевић, Обилић) - фолклорне мијене у имену косовског јунака / Радмило Маројевић. - Стр. 257-262.

50. Iz onomastičke istorije. [1.] Od Cetinje vode do Rijeke Crnojevića / Radmilo Marojević. - Intervju, Beograd, 16. februar 1990, br. 227, стр. 30.

51. Iz onomastičke istorije. [2.] Folklorne mene u imenu kosovskog junaka / Radmilo Marojević. - Intervju, Beograd, 2. mart 1990, br. 228, стр. 36-37.

52. Iz onomastičke istorije. [3.] Od Kosova polja do Kosova političkog jezika / Radmilo Marojević. - Intervju, Beograd, 30. mart 1990, br. 230, стр. 26-27.

53. Iz onomastičke istorije. [4.] Ne zna kako se preziva / Radmilo Marojević. - Intervju, Beograd, 13. april 1990, br. 231, стр. 39-40.

54. Iz onomastičke istorije. [5.] Od Podgorice do Titograda, i natrag / Radmilo Marojević. - Intervju, Beograd, 27. april 1990, br. 232, стр. 36-37.

55. Iz onomastičke istorije. [6.] Starija Gorica od Crne Gore / Radmilo Marojević. - Intervju, Beograd, 11. maj 1990, br. 233, стр. 42-43.

56. Iz onomastičke istorije. [7.] Memorijalna toponimija / Radmilo Marojević. - Intervju, Beograd, 8. jun 1990, br. 235, стр. 36-37.

57. Iz onomastičke istorije. [8.] Personalna imena gradova / Radmilo Marojević. - Intervju, Beograd, 22. jun 1990, br. 236, стр. 38-39.

58. Из ономастике Дробъака (Петњица, Пошћење, Пута) / Радмило Маројевић. - Дурмиторски зборник: На извору Вукова језика. [1]. (Зборник радова са научног скупа одржаног у Шавнику 7. и 8. јула 1988). Титоград, 1991, стр. 57-60. [Резиме на руском језику].

59. Пирогощая в „Слове о полку Игореве” и древнерусских летописях / Р. [Радмило] Мароевич. - Научные доклады высшей школы. Филологические науки, Москва, 1993, № 1, стр. 80-84. 
60. Патронимы в системе категорий принадлежности древнерусского языка / Р. [Радмило] Мароевич. - Общеславянский лингвистический атлас: Материалы и исследования. 1988-1990. Москва: Наука, 1993, стр. 103-116.

61. Методологические вопросы словообразовательно-семантической реконструкиии древнеславянских топонимов / Р. [Радмило] Мароевич. - XI. medzinarodný zjazd slavistov. Zborník resume. Bratislava, 1993, стр. 668-669.

62. Проф. др Радмило Маројевић о српском језику: када су настала презимена. [Сажету верзију излагања приредила] А. [Александра] Бркић. - Политика, Београд, 27. јун 1993, стр. 8.

63. Речи чувају тајне: Ни Козирјев, ни Козирев... / Радмило Маројевић и Богдан Терзић. Приредила: Александра Бркић. - Политика, Београд, 18. јул 1993, стр. 10. (Слово о језику).

64. О Цариграду / Радмило Маројевић. Приредила: Александра Бркић. - Политика, Београд 1. август 1993, стр. 10. (Слово о језику).

65. Пресушила река, остало име: Како су од Цетиње воде и Цетиња врела настали Цетиње поље и Ријека Црнојевића / Радмило Маројевић. Приредила: Александра Бркић. - Политика, Београд, 5. септембар 1993, стр. [12]. (Слово о језику).

66. Семантичка двопланост посесивних изведеница типа нванъковаг у староруском језику. (Уз тумачења граматике и семантике облика у руској историјској лингвистици) / Радмило Маројевић. - Зборник Матице српске за филологију и лингвистику, Нови Сад, 1994, [књ.] XXXVII, стр. 339-346.

67. Семантическая двуплановость посессивных производных типа Иваньковая 8 древнерусском языке: (к толкованию грамматики и семантики формы в русском историческом языкознании) / Р. [Радмило] Мароевич. - Научные доклады высшей школы. Филологические науки, Москва, 1995, № 3, стр. 86-94.

68. Ономатолошки прилози. Књ. ХІІ. Београд, 1996:

1. Историјски развој словенских посесивних изведеница у антропонимији и топонимији: (са социоономастичког и творбено-семантичког аспекта) / Радмило Маројевић. - Стр. 1-7. [Резиме на руском језику].

2. Из ономастичке историје. 3. Словенски антропоними типа Томаш, топоним Париж и апелатив папеж - резултат творбене адаптације / Радмило Маројевић. - Стр. 17-22. [Резиме на руском језику].

69. Словенска историјска антропонимија: (из пољског угла) / Радмило Маројевић. - Сто година полонистике у Србији. Зборник радова са јубиларног научног скупа: Београд, јануар 1996. Београд, 1996, стр. 115-119. [Резиме на пољском језику].

70. Методологические вопросы реконструкиии древнеславянских топонимов: (деривационно-семантический и дериваџионно-фонетический аспекты) / Р. [Радмило] Мароевич. - Ономастика та етимологія. Збірник наукових праць на честь 65-річчя Ірини Михайлівни Желєзняк. Київ, 1997, стр. 151-170.

71. Имена собственные в списках повести о князе Михаиле тверском / Р. [Радмило] Мароевич. - Михаил Тверской: личность, эпоха, наследие. Материалы международной конференции, посвященной 725-летию со дня рождения Михаила 
Ярославича - великого князя тверского и владимирского (г. Тверь, 27-29 ноября 1996 г.). Тверь, 1997, стр. 244-249.

72. Заметки по историческому словообразованию. 5-7 / Р. [Радмило] Мароевич. - Этимология: 1994-1996. Москва: Наука, 1997, стр. 100-105.

〜 5. Славянские антропонимы типа Томашь / Радмило Мароевич. - Стр. 100-103.

6. Ст.-слав. папежь / Радмило Мароевич. - Стр. 103.

7. Славянская форма топонима Парижь / Радмило Мароевич. - Стр. 103-105.

73. Методологические вопросы реконструкиии древнеславянских топонимов (деривачионно-семантический и деривационно-фонетический аспекты) / Р. [Радмило] Мароевич. - Вопросы языкознания, Москва, 1997, № 3, стр. 76-88; 1998, № 2, стр. 59: Примечания к предыдущей статье Р. [Радмило] Мароевича (ВЯ 1997/3).

74. Студије српске и словенске. Серија І. Српски језик. Београд. 1997, II, бр. 1-2:

1. Присвојни придеви (possessiva) у старославенском језику / Радмило Маројевић. - Стр. 153-183. [Резиме на руском језику].

2. Studia palaeoslavica. II (Старославенски неадаптирани облик литоус

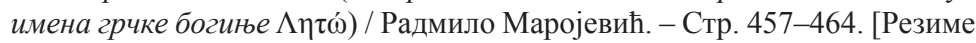
на руском језику].

75. Имена по мужу у старословенском језику / Радмило Маројевић. - Зборник Матице српске за филологију и лингвистику, Нови Сад, 1997, [књ.] XL/2, стр. 179-183. [Резиме на руском језику].

76. Имена по мужу у старословенском језику / Радмило Маројевић. [Нови Сад: Матица српска, 1997], стр. 179-183. (П. о.: Зборник Матице српске за филологију и лингвистику; 40, 2, 1997).

77. Уместо предговора / Радмило Маројевић. - [У:] Михаило Шћепановић. Именослов ваљевске Петниие. Београд-Ваљево, 1997, стр. 11-12.

78. Этюды по грамматике древнерусского языка. II (Посессивы типа Tvorimíričь) / $\mathrm{P}$. [Радмило] Мароевич. - Вопросы языкознания, Москва, 1998, № 2, стр. 51-59.

79. Студије српске и словенске. Серија I. Српски језик. Београд. 1998, III, бр. 1-2:

1. Лична имена у систему антропонимских категорија прасловенског језика / Радмило Маројевић. - Стр. 5-12. [Резиме на руском језику].

80. Јован Вуковић као компаративиста и палеослависта. (Увод. Фрагменти 1-3)/ Радмило Маројевић. - Личност и дјело академика Јована Вуковића. Реферати са Научног скупа, одржаног у Београду 29. и 30. јуна 1998. године. Београд, 1998, стр. $31-36$.

81. Личные имена в системе антропонимических категорий праславянского языка / Р. [Радмило] Мароевич. - Проблеми слов'янської ономастики: Збірник наукових праць. Ужгород, 1999, стр. 105-112.

82. Српски језик данас. [Зборник радова] / Радмило Маројевић. Београд: Српска радикална странка, ЗИПС, 2000, 416 стр. (Библиотека Serbica. Књига I).

83. Старославенске студије / Радмило Маројевић. Београд: Филолошки факултет - Крагујевац: ИДП „Нова светлост” (Библиотека Лицеј, књ. V), 2000, 159 стр. (Palaeoslavica serbica, књ.I). 
84. Личные имена в системе антропонимических категорий праславянского языка / Р. [Радмило] Мароевич. - Этимология: 1997-1999. Москва, 2000, стр. 96-102.

85. Студије српске и словенске. Серија I. Српски језик. Београд. 2001, VI, бр. 1-2:

2. Секундарни женски антропоними на подручу источне и старе Херцеговине / Радмило Маројевић, Раде Р. Лаловић. - Стр. 197-203. [Резиме на енглеском језику].

86. О Марчу у Горском вијениу / Радмило Маројевић. - Зборник за српски језик, књижевност и умјетности, Бања Лука, 2002, II, бр. 2, стр. 43-65. [Резиме на руском језику].

87. Српски језик данас [1]. [Зборник радова]. Друго издање. Београд: Бард-фин - Бања Лука: Романов, 2008, 219 стр. (Библиотека Сербика. Књига I).

88. Српски именослов. I (1. Прача и 2. Устипрача) / Радмило Маројевић. - Радови Филозофског факултета / Универзитет у Источном Сарајеву, Пале, 2010, бр. 12, књ. 1: Филолошке науке. стр. 253-258. [Резиме на руском језику].

89. Олег Николајевич Трубачов и словенска етимологија топонима Врбас: десет година од смрти слависте који је обиљежио епоху (1930-2002) / Радмило Н. Маројевић. - Филолог, Бања Лука, 2012, књ. V, стр. 127-135. [Резиме на руском језику].

90. Старославенске студије / Радмило Маројевић. Бања Лука: Panevropski univerzitet Apeiron Banja Luka, 2015, 159 стр. (Palaeoslavica serbica, књ.I).

91. Посесивне категорије у руском језику: (у своме историјском развитку и данас)/ Радмило Маројевић. Бања Лука: Panevropski univerzitet Apeiron Banja Luka, 2015, 206 стр.

92. Посесивне изведенице у староруском језику: Антропонимски систем. Топонимија. „Слово о полку Игореве” / Радмило Маројевић. Београд [= Бања Лука]: Panevropski univerzitet Apeiron Banja Luka, 1985 [=2015], 158 стр.

93. Српски језик данас. [Зборник радова] / Радмило Маројевић. Бања Лука: Panevropski univerzitet Apeiron Banja Luka, 2016. (Библиотека Serbica. Књига I).

\section{ЛИТЕРАТУРА}

Бошковић 1978: Радосав Бошковић, Одабрани чланщи и расправе, ЦАНУ Титоград.

Воронина Игрошева 1987: И. И. Воронина, А. В. Грошева, Об албанском су фиксе -ar и его латинском прототипе -arius, Romano - balcanica (вопросы адаптации латинского яазык кого элемента в балканском ареале). Ленинград.

Грковић 1983: Милица Грковић, Имена у Дечанским хрисовуљама, Филозофски факултет, Нови Сад. 
Даничић 1863 - 1864: Ђуро Даничић, Рјечник из књижевних старина српских, I - III, Београд.

Ивић 1998: Павле Ивић, Преглед историје српског језика, Целокупна дела VIII, Издавачка књижарница Зорана Стојановића, Сремски Карловци, Нови Сад.

Караџић 1977: Вук Стеф. Караџић, Српске народне пјесме, књига II, Просвета, Београд.

Лома 2002: Александар Лома, Пракосово. Словенски индоевропски корени српске епике, Балканолошки институт, Београд.

Михајловић 2002: Велимир Михајловић, Српски презименик, Аурора, Нови Сад.

Пешикан 1981: Митар Пешикан, Из историјске топонимије Подримља, Ономатолошки прилози САНУ, књига II, Београд.

Пешикан 1982-1984: Митар Пешикан, Зетско-хумско-рашка имена на почетку турскога доба, Ономатолошки прилози, III-V, САНУ, Београд.

PJA3У: Rječnik hrvatskoga ili srpskoga jezika

Скок 1971: Petar Skok, Etimologijski rječnik hrvatskoga ili srpskoga jezika I-IV, JAZU, Zagreb.

\section{ОНОМАСТИЧЕСКИЕ ВОПРОСЫ (И РЕШЕНИЯ) ПРОФЕССОРА РАДМИЛО МАРОЕВИЧА \\ Резюме}

В настоящей статье автор рассматривает научный вклад профессора Мароевича, одного из важнейших основоположников сербской ономастики, учёного, который своими научными решениями проливал свет на тёмные места сербской ономастической карты.

Указывая на выдвинутый профессором методологический подход к решению ономастических вопросов, являющийся основой для нынешних и будущих исследований в сербистике, указываем и на ключевые тематические решения вопросов в ономастике (в антропонимике и топонимике), которые, на основе работ Мароевича, протоптали дорогу будущим исследователям в данной области ономастических исследований.

Ключевые слова: ономастика, антропонимика, топонимика, методологический подход, притяжательные суффиксы, следы двойственного числа, Радмило Мароевич. 